\title{
B-cell translocation gene 1 serves as a novel prognostic indicator of hepatocellular carcinoma
}

\author{
MITSURO KANDA $^{1}$, HIROYUKI SUGIMOTO ${ }^{1}$, SHUJI NOMOTO ${ }^{1}$, HISAHARU OYA ${ }^{1}$, SOKI HIBINO ${ }^{1}$, \\ DAI SHIMIZU $^{1}$, HIDEKI TAKAMI ${ }^{1}$, RYOJI HASHIMOTO ${ }^{1}$, YUKIYASU OKAMURA ${ }^{2}$, \\ SUGURU YAMADA $^{1}$, TSUTOMU FUJII ${ }^{1}$, GORO NAKAYAMA ${ }^{1}$, MASAHIKO KOIKE ${ }^{1}$, \\ MICHITAKA FUJIWARA $^{1}$ and YASUHIRO KODERA ${ }^{1}$
}

${ }^{1}$ Department of Gastroenterological Surgery (Surgery II), Nagoya University Graduate School of Medicine, Nagoya, Aichi 466-8550; ${ }^{2}$ Division of Hepato-Biliary-Pancreatic Surgery, Shizuoka Cancer Center, Shizuoka 411-8777, Japan

Received September 17, 2014; Accepted October 30, 2014

DOI: $10.3892 /$ ijo.2014.2762

\begin{abstract}
Although the B-cell translocation gene 1 (BTGl) plays an important role in apoptosis and negatively regulates cell proliferation, $B T G 1$ expression in hepatocellular carcinoma (HCC) has not been evaluated. In this study expression analysis of $B T G 1$ was conducted to clarify the role of $B T G 1$ in the initiation of HCC carcinogenesis and progression. BTGI mRNA expression levels were determined for HCC cell lines and 151 surgical specimen pairs using quantitative real-time reverse transcription polymerase chain reaction (RT-qPCR) assay. The mutational and methylation status of HCC cell lines were analyzed via high resolution melting (HRM) analysis and direct sequencing analysis to elucidate the regulatory mechanisms of $B T G 1$ expression. The expression and distribution of the BTG1 protein in liver tissues were evaluated using immunohistochemistry (IHC). Decreased expression of BTGI mRNA was confirmed in the majority of HCC cell lines (89\%) and clinical HCC tissues (85\%) compared with non-cancerous liver tissues. Mutations or promoter hypermethylation were not identified in HCC cell lines. BTGl mRNA expression levels were not influenced by background liver status. The pattern of $B T G 1$ protein expression was consistent with that of BTG1 mRNA. Downregulation of BTGl mRNA in HCC was significantly associated with shorter disease-specific and recurrence-free survival rates. Multivariate analysis of disease-specific survival rates identified BTGl mRNA downregulation as an independent prognostic factor for HCC (hazard ratio 2.12, 95\% confidence interval 1.12-4.04,
\end{abstract}

Correspondence to: Dr Mitsuro Kanda, Department of Gastroenterological Surgery (Surgery II), Nagoya University Graduate School of Medicine, 65 Tsurumai-cho, Showa-ku, Nagoya, Aichi 466-8550, Japan

E-mail: m-kanda@med.nagoya-u.ac.jp

Key words: B-cell translocation gene 1, hepatocellular carcinoma, tumor suppressor, expression, prognosis
$\mathrm{P}=0.022)$. Our results indicate that altered $B T G 1$ expression might affect hepatocarcinogenesis and may represent a novel biomarker for $\mathrm{HCC}$ carcinogenesis and progression.

\section{Introduction}

Hepatocellular carcinoma (HCC) is the sixth most common cancer and the third most common cause of cancer-related mortality worldwide. HCC is also the leading cause of death among cirrhotic patients $(1,2)$. Most HCC cases occur in sub-Saharan Africa and Eastern Asia; however, the incidence rate has been increasing in some developed countries, including Japan, the United Kingdom, France, and the United States $(3,4)$. All patients diagnosed with advanced stages of the disease exhibit very limited survival, and to date, only treatment with the multikinase inhibitor sorafenib has improved survival rates for these patients $(5,6)$.

In contrast to most other solid tumors, the underlying cirrhotic liver disease found in HCC patients greatly complicates the tumor-related prognosis, which presents a unique situation in which accurate prognostic prediction is a relevant and unmet need $(2,7,8)$. Chronic inflammation induced by chronic viral hepatitis, alcohol consumption or aflatoxin and subsequent hepatocyte regeneration are underlying causes of HCC (9). Continuous inflammation occasionally damages DNA in the hepatocytes of the regenerating liver and thereby increases the chance of developing a gene alteration that may lead to carcinogenesis. The molecular profiling of HCC has led to a better understanding of the physiopathology of this neoplasm and has allowed the development of novel therapeutic approaches (e.g., molecular targeted therapies) for tumors previously considered to be therapy-refractory $(10,11)$. Integrative analyses of genetic and epigenetic information obtained for the tumor and the surrounding tissue should be used to identify novel biomarkers and therapeutic targets in HCC to improve existing treatment algorithms and eventually design a more personalized therapy for this devastating disease $(12,13)$.

We have identified several HCC-related genes by expression and epigenetic analyses $(14,15)$. From the exhaustive expression analysis obtained via our microarray data, the 
B-cell translocation gene 1 (BTGl) was identified as a candidate tumor suppressor gene for HCC. Human BTG1, which is localized to chromosome $12 \mathrm{q} 22$, was originally identified as a translocation partner of the $c-M y c$ gene in a case of B-cell chronic lymphocytic leukemia and belongs to a family of antiproliferative genes (16-18). BTG1 is constitutively expressed in quiescent cells, and its expression is downregulated as cells enter the growth cycle $(19,20)$. Experiments in which gene expression was induced showed that BTG1 is a Bcl-2-regulated mediator of apoptosis and that it negatively regulates cell proliferation in breast and ovarian cancer $(20,21)$. However, the role of BTG1 in gastroenterological malignancies including $\mathrm{HCC}$ remains unclear.

The aims of this study were to evaluate the clinical significance of BTG1 expression, examine the regulatory factors involved in BTG1 transcription, clarify the roles of BTG1 in hepatocarcinogenesis and its subsequent progression, and propose a potential diagnostic and therapeutic molecular target for $\mathrm{HCC}$.

\section{Materials and methods}

Ethics. This study conformed to the ethical guidelines of the World Medical Association Declaration of Helsinki - Ethical Principles for Medical Research Involving Human Subjects and has been approved by the Institutional Review Board of Nagoya University, Aichi, Japan (no. 2013-0295). Written informed consent for usage of clinical samples and data, as required by the Institutional Review Board, was obtained from all patients.

Sample collection. Nine HCC cell lines (Hep3B, HepG2, HLE, HLF, HuH1, HuH2, HuH7, PLC/PRF/5 and SK-Hep1) were obtained from the American Type Culture Collection (Manassas, VA, USA). Primary HCC tissues and corresponding non-cancerous tissues were collected from 151 consecutive patients undergoing liver resection for HCC at Nagoya University Hospital between January, 1998 and January, 2012. Treatment after recurrence generally included the following options: surgery, radiofrequency ablation, transcatheter arterial chemoembolization, and chemotherapy according to tumor status and liver function.

Tissue samples were collected, immediately flash frozen in liquid nitrogen and stored at $-80^{\circ} \mathrm{C}$ until RNA extraction (28 days on average) was performed. Tumor samples $\sim 5 \mathrm{~mm}^{2}$ in size that did not contain a necrotic component and were confirmed to contain $>80 \%$ tumor cells by definition were used for RNA extraction. Corresponding non-cancerous liver tissue samples were collected $>2 \mathrm{~cm}$ away from the edge of the tumor, were obtained from the same patient and did not contain any regenerative or dysplastic nodules.

Microarray procedure. Sample collection, RNA extraction, and Affymetrix HG-U133A and HG-U133B GeneChip (Affymetrix, Inc., Santa Clara, CA, USA) gene expression arrays were performed as previously described (22-24).

Quantitative real-time reverse transcription polymerase chain reaction $(R T-q P C R)$. The BTGl mRNA expression levels were analyzed by RT-qPCR. Total RNA (10 $\mu \mathrm{g}$ per sample) was isolated and used to generate complementary DNA. The primer sequences used in this study are listed in Table I. RT-qPCR was performed on nine HCC cell lines and 151 pairs of clinical samples with a SYBR-Green PCR Core Reagents kit (Perkin-Elmer/Applied Biosystems, Inc., Foster City, CA, USA) and included no-template samples as a negative control. Real-time detection of the SYBR-Green emission intensity was conducted with an ABI StepOnePlus Real-Time PCR system (Perkin-Elmer/Applied Biosystems, Inc.). The expression of glyceraldehyde-3-phosphate dehydrogenase $(G A P D H)$ mRNA was quantified in each sample for standardization. For cell lines, biological replicates were tested in triplicate. Technical replicates were performed in triplicate for both cell lines and HCC tissues. The expression levels for each sample are shown as the BTG1 value divided by the $G A P D H$ value. $B T G 1$ mRNA expression was considered to be downregulated in tumor tissues when its level was $<40 \%$ of the level in the corresponding non-cancerous tissues.

Mutational analysis. The BTG1 gene consists of two exons. Mutational surveillance of HCC cell lines was performed in exon 1 and 2 of the BTGl gene by high resolution melting (HRM) analysis. HRM is known to be a reliable and concise technique for the detection of genetic alterations (25-27). Genomic DNA obtained from HCC cell lines was amplified with specific primer pairs according to the manufacturer's instructions (Life Technologies, Carlsbad, CA, USA). All samples were tested in triplicate. Eight wells of each PCR plate were allocated to wild-type control DNA, and one well contained a non-template control to validate the PCR. HRM was conducted using a StepOnePlus instrument (Life Technologies) with a melting temperature range set between 60 and $98^{\circ} \mathrm{C}$. Scanning data were analyzed by HRM software v3.0.1 (Life Technologies). The primers used for mutational analysis are listed in Table I.

Bisulfite sequencing analysis. The BTG1 gene contains a CpG island near the promoter region; thus, we hypothesized that aberrant methylation is responsible for regulating BTGl transcription in HCC. Genomic bisulfite-treated DNA from HCC cell lines was sequenced to ascertain the levels of DNA methylation. The bisulfite treatment and sequencing procedures were performed as previously reported $(28,29)$.

Immunohistochemistry (IHC). IHC was performed to investigate $B T G 1$ protein localization in 48 representative sections of well-preserved HCC tissue as described previously (30). Sections were incubated for $1 \mathrm{~h}$ at room temperature with a rabbit antibody directed against BTG1 (PA5-25035; Thermo Fisher Scientific, Inc., Rockford, IL, USA) diluted 1:100 in Antibody Diluent (Dako, Carpinteria, CA, USA) and then developed for 2 min using liquid 3,3'-diaminobenzidine as the substrate (Nichirei Corp., Tokyo, Japan). The staining patterns were compared between HCC tissue and the corresponding non-cancerous tissue. The intensity of BTGl protein expression was graded depending on the percentage of stained cells as follows: no staining, minimal $(<30 \%)$; focal $(30-70 \%)$; and diffuse $(>70 \%)$ (31). To avoid subjectivity, specimens were randomized and coded before analysis by two independent observers blinded to the status of the samples. Each observer 
Table I. Primers and annealing temperature.

\begin{tabular}{|c|c|c|c|c|c|}
\hline Gene & Experiment & Type & $\begin{array}{l}\text { Sequence } \\
\left(5^{\prime} \rightarrow 3^{\prime}\right)\end{array}$ & $\begin{array}{l}\text { Product } \\
\text { size (bp) }\end{array}$ & $\begin{array}{c}\text { Annealing } \\
\text { temperature }\left({ }^{\circ} \mathrm{C}\right)\end{array}$ \\
\hline \multirow[t]{4}{*}{ BTG1 } & RT-qPCR & $\begin{array}{l}\text { Forward } \\
\text { Reverse }\end{array}$ & $\begin{array}{l}\text { CTGCAGACCTTCAGCCAGA } \\
\text { CGAATACAACGGTAACCCGA }\end{array}$ & 104 & 60 \\
\hline & $\begin{array}{l}\text { Exon } 1 ; \mathrm{HRM} \\
\text { sequencing }\end{array}$ & $\begin{array}{l}\text { Forwarvd } \\
\text { Reverse }\end{array}$ & $\begin{array}{l}\text { CATCGCTCGTCTCTTCCTCT } \\
\text { GACTCTGACCCAGGGATGTG }\end{array}$ & 419 & 54 \\
\hline & $\begin{array}{l}\text { Exon 2; HRM } \\
\text { sequencing }\end{array}$ & $\begin{array}{l}\text { Forward } \\
\text { Reverse }\end{array}$ & $\begin{array}{l}\text { CGATCCTAAGCGTTGTTTCTC } \\
\text { TCCATAATCCATCCCCAAGA }\end{array}$ & 497 & 56 \\
\hline & $\begin{array}{l}\text { Bisulfite } \\
\text { sequencing }\end{array}$ & $\begin{array}{l}\text { Forward } \\
\text { Reverse }\end{array}$ & $\begin{array}{l}\text { GTGGTATTATAAAGGGTGTTG } \\
\text { AАССТCСССААСTACСТCC }\end{array}$ & 118 & 62 \\
\hline$G A P D H$ & RT-qPCR & $\begin{array}{l}\text { Forward } \\
\text { Probe } \\
\text { Reverse }\end{array}$ & $\begin{array}{l}\text { GAAGGTGAAGGTCGGAGTC } \\
\text { CAAGCTTCCCGTTCTCAGCC } \\
\text { GAAGATGGTGATGGGATTTC }\end{array}$ & 226 & 60 \\
\hline
\end{tabular}

$B T G 1$, B-cell translocation gene 1; GAPDH, glyceraldehyde-3-phosphate dehydrogenase; RT-qPCR, quantitative real-time reverse transcription polymerase chain reaction; HRM, high resolution melting.

Table II. Microarray results for BTG1 expression.

\begin{tabular}{|c|c|c|c|c|c|c|c|}
\hline Gene & $\begin{array}{l}\log _{2} \\
\text { ratio }\end{array}$ & $\begin{array}{c}\text { Normal } \\
\text { signal }\end{array}$ & Detection & $\begin{array}{l}\text { Tumor } \\
\text { signal }\end{array}$ & Detection & $\begin{array}{l}\text { Probe } \\
\text { ID }\end{array}$ & $\begin{array}{c}\text { Chromosomal } \\
\text { location }\end{array}$ \\
\hline \multirow[t]{2}{*}{ BTG1 } & -1.6 & 2544.9 & Positive & 757.1 & Positive & $\begin{array}{c}\text { HU133p2 } \\
-10370\end{array}$ & Chr 12q22 \\
\hline & -1.5 & 1389 & Positive & 418.8 & Positive & $\begin{array}{c}\text { HU133p2 } \\
-10369\end{array}$ & Chr 12q22 \\
\hline
\end{tabular}

$B T G 1$, B-cell translocation gene 1.

evaluated all the specimens at least twice within a given time interval to minimize intra-observer variation.

Statistical analysis. The values between the two groups were analyzed using the Mann-Whitney $U$ test. The $\chi^{2}$ test was used to analyze the association between the expression status of BTGl and clinicopathological parameters. The strength of the correlation between two variables was assessed by Spearman's rank correlation coefficient. Disease-specific and -free survival rates were calculated using the Kaplan-Meier method, and the difference in survival curves was analyzed using the log-rank test. We performed multivariable regression analysis to detect prognostic factors using the Cox proportional hazards model, and variables with $\mathrm{P}<0.05$ were entered into the final model. All statistical analysis was performed using JMP 10 software (SAS Institute, Inc., Cary, NC, USA). $\mathrm{P}<0.05$ was considered statistically significant.

\section{Results}

Patient characteristics. The age of the 151 patients ranged from 34-84 years (median 64 years), and the male-to-female ratio was 126:25. Thirty-seven patients presented with hepatitis B infections, and 84 patients presented with hepatitis $\mathrm{C}$ infections. In terms of the non-cancerous liver samples, the number of patients with normal liver, chronic hepatitis, and cirrhosis were 10,87 , and 54, respectively. When classified according to the 7 th edition of the UICC classification, 84,39 and 18 patients were in stages I, II and III, respectively.

Expression array. Gene expression that was reduced further in tumor tissues than in the corresponding non-cancerous tissues was used to identify new candidate tumor suppressors in HCC. BTG1 expression was reduced in HCC compared with normal tissue, with a $\log _{2}$ ratio of -1.6 and -1.5 (Table II).

BTG1 mRNA expression and regulatory mechanisms in HCC cell lines. Decreases in BTG1 mRNA were confirmed in eight (89\%) of the nine HCC cell lines compared with the median expression level in non-cancerous liver tissues; these results demonstrate the heterogeneity of BTGl expression in HCC cell lines (Fig. 1A). No mutations were detected by the HRM analysis of BTG1 exons 1 and 2 (Fig. 1B). Direct nucleotide sequence analysis of bisulfite-treated GC cell lines showed absence of hypermethylation of BTGl promoter region in all GC cell lines (Fig. 1C). 
A

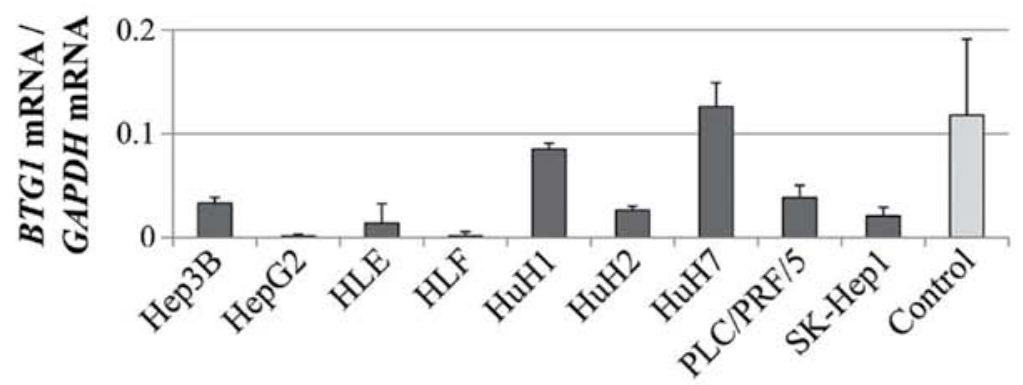

B
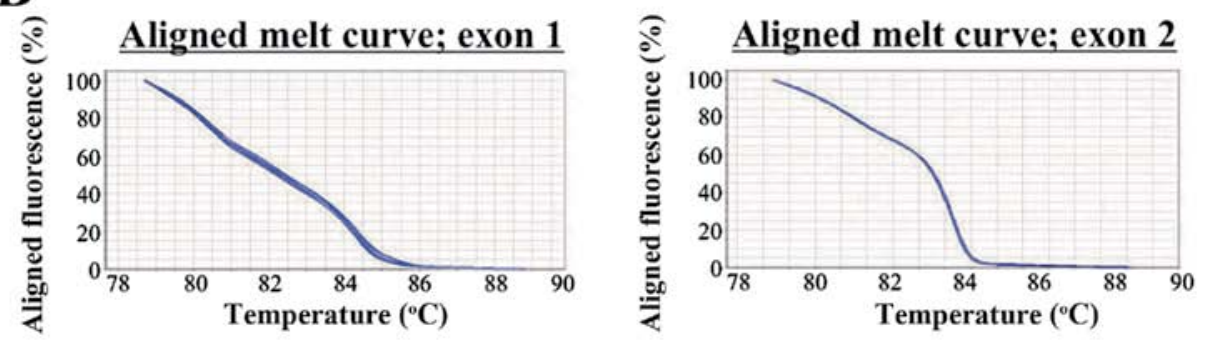

C

HepG2

$\underline{\mathrm{HuH} 2}$

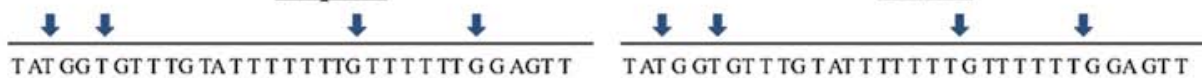

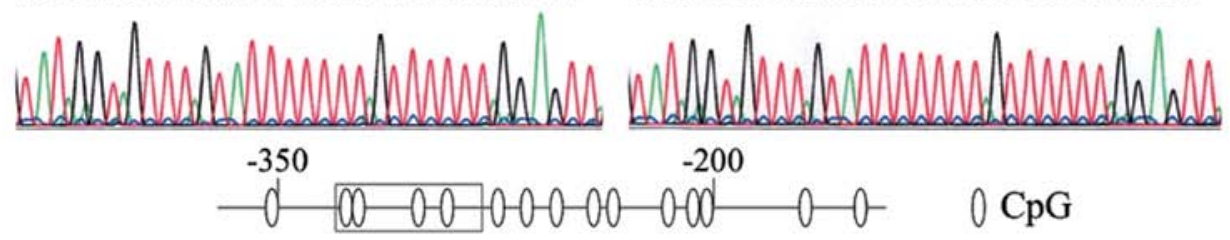

D

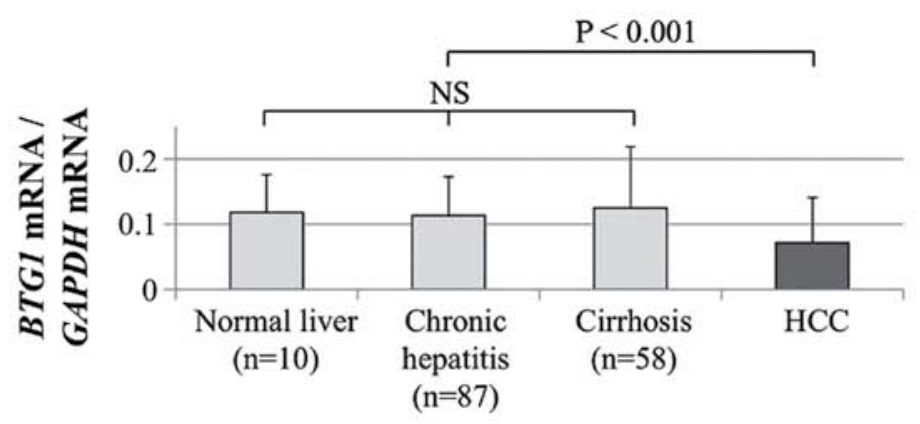

Figure 1. (A) Expression status of B-cell translocation gene 1 (BTG1) in hepatocellular carcinoma (HCC) cell lines. BTG1 mRNA expression in HCC cell lines and control samples (median value of 151 non-cancerous tissues) by quantitative real-time reverse transcription polymerase chain reaction (RT-qPCR). Compared with the control cell lines, reduced expression was confirmed in all the HCC cell lines except for HuH1 and HuH7. (B) Results of the high-resolution melting (HRM) analysis for BTG1 exon 1 and 2. No mutations were detected. (C) Representative results of the bisulfite sequencing analysis. All CpGs were converted to TG. (D) BTG1 expression in clinical specimens. There were no significant differences in the BTG1 mRNA expression levels observed in non-cancerous tissues among the three patient groups categorized by background liver status. HCC tissues showed a lower mean expression of $B T G 1$ mRNA than the corresponding normal tissues. NS, not significant.

Expression status of BTG1 in 151 clinical HCC samples. The BTG1 mRNA expression levels of non-cancerous tissue samples were categorized pathologically into normal liver $(n=10)$, chronic hepatitis $(n=87)$, and cirrhosis $(n=58)$. Upon evaluation of these samples, no significant differences were found, suggesting that the expression of $B T G 1$ mRNA in non-cancerous liver was not affected by background liver fibrosis (Fig. 1D). In 129 (85\%) of 151 patients, the expression level of BTG1 mRNA was lower in the HCC tissues than in the corresponding normal tissues. The HCC tissues exhibited significantly lower expression levels of $B T G 1$ mRNA than the corresponding normal tissues $(\mathrm{P}<0.001$, Fig. 1D).
Expression patterns of the $B T G 1$ protein were evaluated by IHC. Representative cases with downregulated BTGI mRNA expression in HCC tissues exhibited reduced expression of the $B T G 1$ protein in the cytoplasm of the cancerous tissues compared with the adjacent non-cancerous tissues (Fig. 2A). Overall, the staining intensity (shown in Fig. 2B) of the BTGI protein in 48 patients was consistent with the RT-qPCR data (Fig. 2C).

Prognostic values of the expression status of BTG1. Fifty-four of $151 \mathrm{HCC}$ patients showed substantial downregulation $(<40 \%)$ of BTG1 mRNA in HCC tissues compared with non-cancerous 

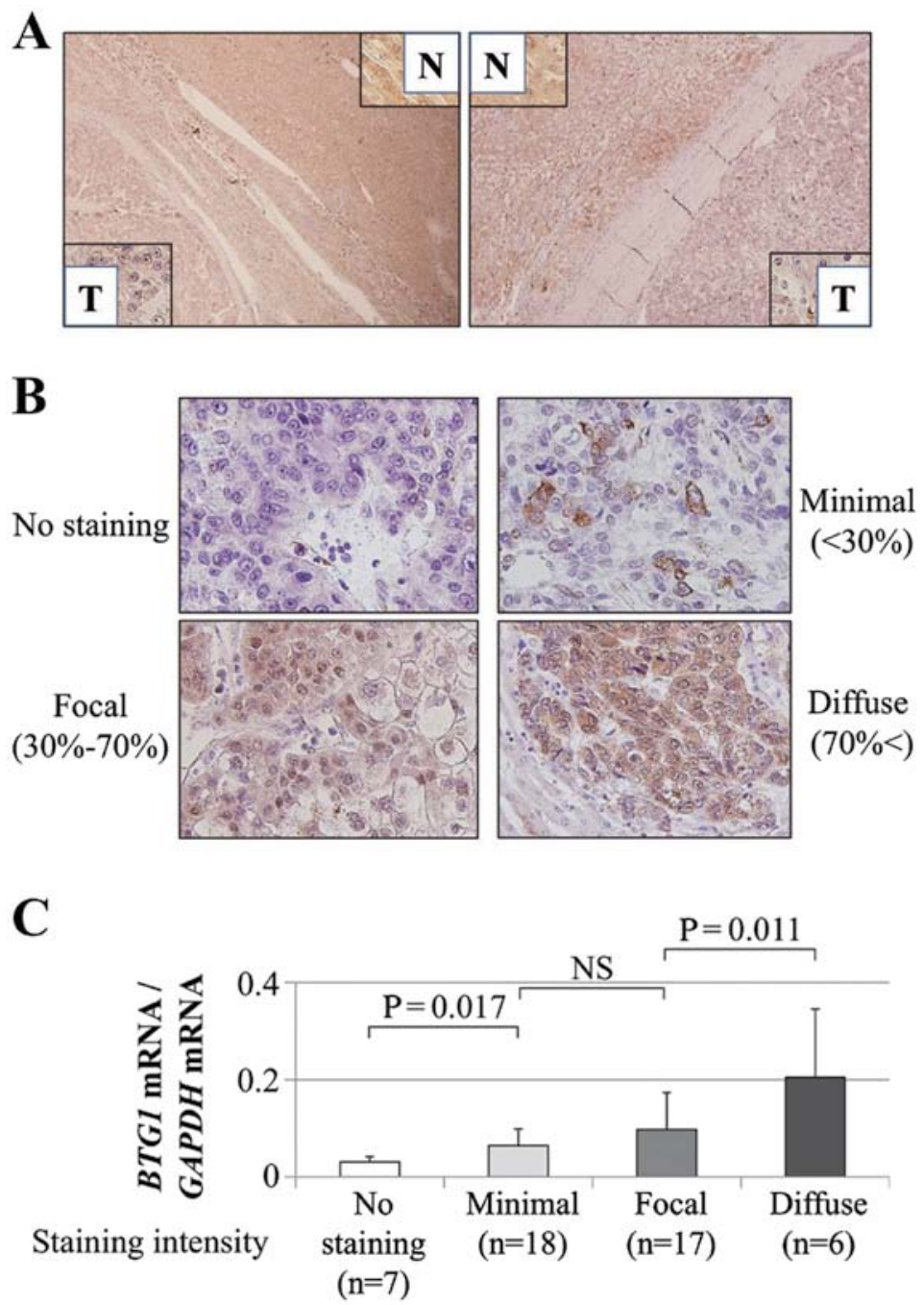

Figure 2. (A) Detection of B-cell translocation gene 1 (BTG1) protein by immunohistochemical staining in two representative hepatocellular carcinoma (HCC) patients. In both samples, the cancerous tissues exhibited reduced BTG1 protein expression compared with the adjacent noncancerous tissues (x100 and x400 magnification). N, non-cancerous tissue component; T, tumor tissue component. (B) Representative cases of each BTG1 staining intensity; no staining, minimal, focal and diffuse (x400 magnification). (C) Staining intensity of BTG1 was associated directly with the expression level of BTG1 mRNA in HCC tissues. NS, not significant.

tissues. The downregulation of BTG1 mRNA in the HCC samples was significantly associated with male gender, protein induced by vitamin $\mathrm{K}$ antagonists (PIVKA) II $>40 \mathrm{mAU} / \mathrm{ml}$, tumor size $\geq 3 \mathrm{~cm}$, tumor differentiation (poorly to moderately differentiated), serosal infiltration, vascular invasion, advanced UICC stage, and extra-hepatic recurrence (Table III). The BTG1 mRNA expression levels in HCC tissues were inversely correlated with preoperative PIVKA II levels (Fig. 3A). Patients exhibiting a downregulation of BTG1 mRNA expression in the HCC samples had a significantly shorter disease-specific survival rate than the other patients (2-year survival rates, 67 and $82 \%$, respectively, Fig. 3B). Multivariate analysis identified the downregulation of BTG1 mRNA as an independent prognostic factor for HCC (hazard ratio $2.12,95 \%$ confidence interval 1.12-4.04, $\mathrm{P}=0.022$, Table IV). In terms of recurrence-free survival rates, patients with a substantial downregulation of BTG1 mRNA in the HCC samples had significantly earlier recurrence rates after surgery than the other patients (2-year recurrence-free survival rates: 39 and $65 \%$, respectively, $\mathrm{P}=0.032$, Fig. $3 \mathrm{C}$ ).

\section{Discussion}

BTG is a nuclear protein that is imported into the nucleus through a nuclear localization signal; its nucleocytoplasmic translocation depends on the stage of cell growth and is mediated by a nuclear export signal (32-34). Accordingly, the BTG family, which is thought to play an intimate role in the proliferation of cancer cells, has attracted attention in recent years $(34,35)$. BTG1 has been shown to enhance homeobox B9-mediated transcription in transfected cells and mediate its antiproliferative function. As shown by DNA fragmentation and nuclear condensation, BTG1 localizes to specific macrophage-rich regions in human lesions and apoptotic cells (36). BTG1 mRNA is abundantly expressed in quiescent endothelial cells and is decreased upon the addition of angiogenic growth factors (19).

In this study, the expression status and regulatory mechanisms of BTGl were investigated in HCC. Following the confirmation that BTG1 mRNA expression is remarkably suppressed in most HCC cell lines, the somatic mutation and 
Table III. Association between expression status of BTG1 mRNA and clinicopathological parameters in $151 \mathrm{HCC}$ patients.

\begin{tabular}{lccc}
\hline Clinicopathological & $\begin{array}{c}\text { Downregulation } \\
\text { of } B T G 1 \text { mRNA (n) }\end{array}$ & $\begin{array}{c}\text { Others } \\
\text { (n) }\end{array}$ & P-value \\
\hline
\end{tabular}

Age

$<65$ year

$\geq 65$ year

19

35

Gender

Male

Female

$0.004^{\mathrm{a}}$

Background liver

Normal liver

Chronic hepatitis

Cirrhosis

Pugh-Childs

classification

A

Hepatitis virus

Absent
HBV
HCV
AFP $(\mathrm{ng} / \mathrm{ml})$
$\leq 20$

$>20$

PIVKA II (mAU/ml)

$\leq 40$

$>40$

Tumor multiplicity

Solitary

Multiple

Tumor size

$<3.0 \mathrm{~cm}$

$\geq 3.0 \mathrm{~cm}$

Differentiation

Well

Moderate to poor

Growth type

Expansive growth

Invasive growth

Serosal infiltration

Absent

Present

Formation of capsule

$$
\begin{aligned}
& \text { Absent } \\
& \text { Present }
\end{aligned}
$$

Infiltration to capsule

$$
\text { Absent }
$$

Present

Septum formation

Absent

Present
Table III. Continued.

\begin{tabular}{lccc}
\hline Clinicopathological & $\begin{array}{c}\text { Downregulation } \\
\text { of } B T G 1 \text { mRNA (n) }\end{array}$ & Others & \\
parameters & (n) & P-value
\end{tabular}

Vascular invasion

$\begin{array}{llll}\text { Absent } & 35 & 79 & 0.025^{\mathrm{a}} \\ \text { Present } & 19 & 18 & \\ \text { Margin status } & & & \\ \text { Negative } & 43 & 80 & 0.668 \\ \text { Positive } & 11 & 17 & \end{array}$

UICC pathological

stage

$\begin{array}{lrr}\text { I } & 26 & 68 \\ \text { II } & 17 & 22 \\ \text { III } & 11 & 7\end{array}$

Extra-hepatic

recurrence

$\begin{array}{llll}\text { Absent } & 33 & 79 & 0.007^{\mathrm{a}} \\ \text { Present } & 21 & 18 & \end{array}$

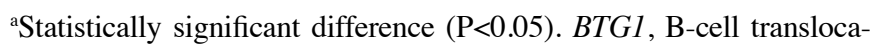
tion gene 1; HCC, hepatocellular carcinoma; HBV, hepatitis B virus; $\mathrm{HCV}$, hepatitis $\mathrm{C}$ virus; AFP, $\alpha$-fetoprotein; PIVKA, protein induced by vitamin K antagonists; UICC, Union for International Cancer Control.

DNA methylation statuses were evaluated as possible mechanisms of suppression. No mutations were detected in any of the HCC cell lines examined by the HRM. In addition, bisulfite sequencing showed absence of hypermethylation in the BTG1 promoter in all GC cell lines. These findings were consistent with those in acute lymphoblastic leukemia (37), and further study will be needed to elucidate the alterative underlying molecular pathway suppressing BTGl transcription.

Interestingly, the expression analysis of clinical samples demonstrated important clinical implications for the expression of BTG1. BTG1 was downregulated in most HCC tissues, and the strong suppression of BTGl was an independent prognostic factor associated with early recurrence. These results indicate that BTGl is a putative tumor suppressor gene that affects both carcinogenesis and the subsequent progression of HCC. The potential use of BTG1 expression as a prognostic biomarker is supported by the finding that $B T G 1$ expression in HCC tissues was inversely correlated with the serum levels of PIVKA II, an important HCC tumor marker.

In clinical practice, aggressive pre- and post-operative systemic therapy could be considered for patients exhibiting strong downregulation of BTG1 identified in biopsies or surgical specimens in anticipation of early recurrence and an adverse prognosis. BTG1 interacts with and regulates the activity of protein arginine methyl transferase (PRMT)1 $(38,39)$. Members of this enzyme family, including PRMT1, are considered global regulators of gene expression that act as transcriptional coregulators of the arginine methylation of histone tails and are critical regulators of transcription (40). Based on our results, the forced expression or artificial modification of interacting molecules (including PRMT1) of 
Table IV. Prognostic factors in 151 patients with hepatocellular carcinoma.

\begin{tabular}{|c|c|c|c|c|c|c|c|}
\hline \multirow[b]{2}{*}{ Variable } & \multirow[b]{2}{*}{$\mathrm{n}$} & \multicolumn{3}{|c|}{ Univariate } & \multicolumn{3}{|c|}{ Multivariable } \\
\hline & & HR & $95 \% \mathrm{CI}$ & P-value & HR & $95 \% \mathrm{CI}$ & P-value \\
\hline Age $(\geq 65)$ & 84 & 1.92 & $1.07-3.57$ & $0.030^{\mathrm{a}}$ & 1.77 & $0.96-3.38$ & 0.069 \\
\hline Gender (male) & 126 & 1.27 & $0.60-3.13$ & 0.553 & & & \\
\hline Background liver (cirrhosis) & 54 & 1.58 & $0.88-2.81$ & 0.123 & & & \\
\hline Pugh-Childs classification (B) & 11 & 0.93 & $0.28-2.32$ & 0.889 & & & \\
\hline $\operatorname{AFP}(>20 \mathrm{ng} / \mathrm{ml})$ & 70 & 1.90 & $1.07-3.42$ & $0.029^{\mathrm{a}}$ & 1.55 & $0.81-2.96$ & 0.181 \\
\hline PIVKA II (>40 mAU/ml) & 93 & 2.10 & $1.14-4.07$ & $0.016^{\mathrm{a}}$ & 1.16 & $0.56-2.51$ & 0.695 \\
\hline Tumor multiplicity (multiple) & 34 & 2.09 & $1.11-3.76$ & $0.023^{\mathrm{a}}$ & 1.77 & $0.91-3.32$ & 0.092 \\
\hline Tumor size $(\geq 3.0 \mathrm{~cm})$ & 104 & 2.20 & $1.13-4.71$ & $0.020^{\mathrm{a}}$ & 1.11 & $0.50-2.62$ & 0.810 \\
\hline Tumor differentiation (well) & 35 & 0.55 & $0.25-1.10$ & 0.095 & & & \\
\hline Growth type (invasive growth) & 24 & 1.44 & $0.69-2.76$ & 0.318 & & & \\
\hline Serosal infiltration & 37 & 2.51 & $1.32-4.61$ & $0.006^{\mathrm{a}}$ & 1.12 & $0.55-2.24$ & 0.742 \\
\hline Formation of capsule & 104 & 1.05 & $0.57-2.02$ & 0.884 & & & \\
\hline Infiltration to capsule & 83 & 1.20 & $0.67-2.18$ & 0.537 & & & \\
\hline Septum formation & 98 & 0.87 & $0.49-1.60$ & 0.651 & & & \\
\hline Vascular invasion & 37 & 3.40 & $1.87-6.07$ & $<0.001^{\mathrm{a}}$ & 2.26 & $1.13-4.55$ & $0.022^{\mathrm{a}}$ \\
\hline Margin status (positive) & 28 & 2.64 & $1.42-4.73$ & $0.003^{\mathrm{a}}$ & 2.30 & $1.21-4.23$ & $0.012^{\mathrm{a}}$ \\
\hline Downregulation of $B T G 1 \mathrm{mRNA}$ & 54 & 2.55 & $1.43-4.57$ & $0.002^{\mathrm{a}}$ & 2.12 & $1.12-4.04$ & $0.022^{\mathrm{a}}$ \\
\hline
\end{tabular}

Univariate analysis was performed using the log-rank test. Multivariate analysis was performed using the Cox proportional hazards model.

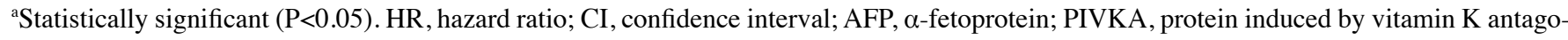
nists; $B T G 1$, B-cell translocation gene 1 .

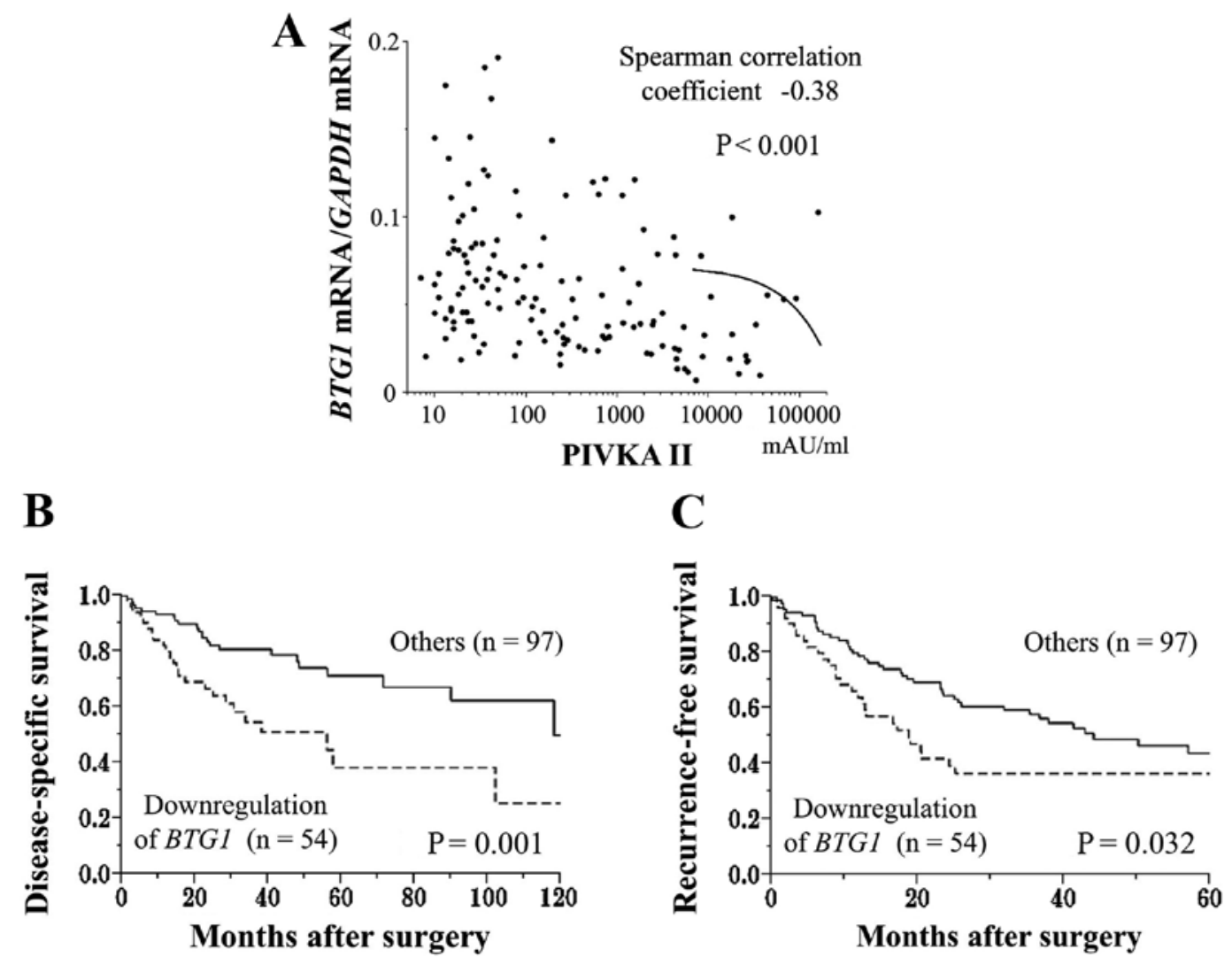

Figure 3. (A) Correlative evaluation between the B-cell translocation gene 1 (BTG1) mRNA expression levels in hepatocellular carcinoma (HCC) tissues and preoperative protein induced by vitamin $\mathrm{K}$ antagonist (PIVKA) II levels. (B and C) Prognostic impact of BTG1 mRNA expression in HCC patients. HCC patients with downregulated BTG1 mRNA had significantly shorter survival rates than patients with normal BTG1 mRNA levels. (B) Disease-specific and (C) recurrence-free survival rates. P-values were calculated using the log-rank test. 
BTG1 may be used as novel therapeutic approaches for the treatment of HCC. For future consideration, external validation is necessary, and functional analysis of the BTGl gene could help to further clarify the role that BTGl plays in the progression of HCC.

In summary, the reduced expression of BTG1 mRNA was associated with early recurrence rates and subsequent poor prognoses in patients with HCC. Our results indicate that altered BTG1 expression might affect hepatocarcinogenesis and may represent a novel biomarker for the initiation of carcinogenesis and the progression of HCC.

\section{References}

1. Parkin DM, Bray F, Ferlay J and Pisani P: Global cancer statistics, 2002. CA Cancer J Clin 55: 74-108, 2005.

2. Llovet JM, Burroughs A and Bruix J: Hepatocellular carcinoma. Lancet 362: 1907-1917, 2003.

3. El-Serag HB: Hepatocellular carcinoma: recent trends in the United States. Gastroenterology 127 (Suppl 1): S27-S34, 2004.

4. Minguez B and Lachenmayer A: Diagnostic and prognostic molecular markers in hepatocellular carcinoma. Dis Markers 31: 181-190, 2011.

5. Llovet JM, Ricci S, Mazzaferro V, et al: Sorafenib in advanced hepatocellular carcinoma. N Engl J Med 359: 378-390, 2008.

6. Miki D, Ochi H, Hayes CN, Aikata H and Chayama K: Hepatocellular carcinoma: towards personalized medicine. Cancer Sci 103: 846-850, 2012.

7. Herath NI, Leggett BA and MacDonald GA: Review of genetic and epigenetic alterations in hepatocarcinogenesis (Review). J Gastroenterol Hepatol 21: 15-21, 2006.

8. Villanueva A, Newell P, Chiang DY, Friedman SL and Llovet JM: Genomics and signaling pathways in hepatocellular carcinoma. Semin Liver Dis 27: 55-76, 2007.

9. Shiraha H, Yamamoto K and Namba M: Human hepatocyte carcinogenesis (Review). Int J Oncol 42: 1133-1138, 2013.

10. Bird A: Perceptions of epigenetics. Nature 447: 396-398, 2007.

11. Khare S, Zhang Q and Ibdah JA: Epigenetics of hepatocellular carcinoma: role of microRNA. World J Gastroenterol 19 : 5439-5445, 2013.

12. Kanda M, Nomoto S, Okamura Y, et al: Detection of metallothionein $1 \mathrm{G}$ as a methylated tumor suppressor gene in human hepatocellular carcinoma using a novel method of double combination array analysis. Int J Oncol 35: 477-483, 2009.

13. Hernandez-Gea V, Toffanin S, Friedman SL and Llovet JM: Role of the microenvironment in the pathogenesis and treatment of hepatocellular carcinoma. Gastroenterology 144: 512-527, 2013.

14. Kanda M, Nomoto S, Nishikawa Y, et al: Correlations of the expression of vascular endothelial growth factor B and its isoforms in hepatocellular carcinoma with clinico-pathological parameters. J Surg Oncol 98: 190-196, 2008.

15. Takami H, Kanda M, Oya H, et al: Evaluation of MAGE-D4 expression in hepatocellular carcinoma in Japanese patients. J Surg Oncol 108: 557-562, 2013.

16. Cho JW, Kim JJ, Park SG, et al: Identification of B-cell translocation gene 1 as a biomarker for monitoring the remission of acute myeloid leukemia. Proteomics 4: 3456-3463, 2004.

17. Lin WJ, Gary JD, Yang MC, Clarke S and Herschman HR: The mammalian immediate-early TIS 21 protein and the leukemia-associated BTG1 proteininteract with a protein-arginine N-methyltransferase. J Biol Chem 271: 15034-15044, 1996.

18. Rouault JP, Rimokh R, Tessa C, et al: BTG1, a member of a new family of antiproliferative genes. EMBO J 11: 1663-1670, 1992.

19. Prévôt D, Voeltzel T, Birot AM, et al: The leukemia-associated protein $\mathrm{Btg} 1$ and the $\mathrm{p} 53$-regulated protein $\mathrm{Btg} 2$ interact with the homeoprotein Hoxb9 and enhance its transcriptional activation. J Biol Chem 275: 147-153, 2000.
20. Zhao Y, Gou WF, Chen S, Takano Y,Xiu YL and Zheng HC: BTG1 expression correlates with the pathogenesis and progression of ovarian carcinomas. Int J Mol Sci 14: 19670-19680, 2013.

21. Sheng SH, Zhao CM and Sun GG: BTG1 expression correlates with the pathogenesis and progression of breast carcinomas. Tumour Biol 35: 3317-3326, 2014.

22. Kanda M, Nomoto S, Okamura Y, et al: Promoter hypermethylation of fibulin 1 gene is associated with tumor progression in hepatocellular carcinoma. Mol Carcinog 50: 571-579, 2011.

23. Nomoto S, Kanda M, Okamura Y, et al: Epidermal growth factor-containing fibulin-like extracellular matrix protein 1 , EFEMP1, a novel tumor-suppressor gene detected in hepatocellular carcinoma using double combination array analysis. Ann Surg Oncol 17: 923-932, 2010.

24. Okamura Y, Nomoto S, Kanda M, et al: Reduced expression of reelin (RELN) gene is associated with high recurrence rate of hepatocellular carcinoma. Ann Surg Oncol 18: 572-579, 2011.

25. Kanda M, Knight S, Topazian M, et al: Mutant GNAS detected in duodenal collections of secretin-stimulated pancreatic juice indicates the presence or emergence of pancreatic cysts. Gut 62: 1024-1033, 2013.

26. Kanda M, Matthaei $\mathrm{H}, \mathrm{Wu}$ J, et al: Presence of somatic mutations in most early-stage pancreatic intraepithelial neoplasia. Gastroenterology 142: 730-733, 2012.

27. Kanda M, Sadakari Y, Borges M, et al: Mutant TP53 in duodenal samples of pancreatic juice from patients with pancreatic cancer or high-grade dysplasia. Clin Gastroenterol Hepatol 11: 719-730, 2013 .

28. Hibino S, Kanda M, Oya H, et al: Reduced expression of DENND2D through promoter hypermethylation is an adverse prognostic factor in squamous cell carcinoma of the esophagus. Oncol Rep 31: 693-700, 2014

29. Shimizu D, Kanda M, Nomoto S, et al: Identification of intragenic methylation in the TUSC1 gene as a novel prognostic marker of hepatocellular carcinoma. Oncol Rep 31: 1305-1313, 2014.

30. Kanda M, Nomoto S, Oya H, et al: Downregulation of DENND2D by promoter hypermethylation is associated with early recurrence of hepatocellular carcinoma. Int J Oncol 44: 44-52, 2014.

31. Kanda M, Shimizu D, Nomoto S, et al: Prognostic impact of expression and methylation status of DENN/MADD domain-containing protein 2D in gastric cancer. Gastric Cancer: Apr 3, 2014 (Epub ahead of print).

32. Kawamura-Tsuzuku J, Suzuki T, Yoshida Y and Yamamoto T: Nuclear localization of Tob is important for regulation of its antiproliferative activity. Oncogene 23: 6630-6638, 2004.

33. Rodier A, Rochard P, Berthet C, et al: Identification of functional domains involved in BTG1 cell localization. Oncogene 20: 2691-2703, 2001.

34. Winkler GS: The mammalian anti-proliferative BTG/Tob protein family. J Cell Physiol 222: 66-72, 2010.

35. Buitenkamp TD, Pieters R, Zimmermann M, et al: BTG1 deletions do not predict outcome in Down syndrome acute lymphoblastic leukemia. Leukemia 27: 251-252, 2013.

36. Lee H, Cha S, Lee MS, Cho GJ, Choi WS and Suk K: Role of antiproliferative B cell translocation gene-1 as an apoptotic sensitizer in activation-induced cell death of brain microglia. J Immunol 171: 5802-5811, 2003.

37. Waanders E, Scheijen B, van der Meer LT, et al: The origin and nature of tightly clustered BTG1 deletions in precursor B-cell acute lymphoblastic leukemia support a model of multiclonal evolution. PLoS Genet 8: e1002533, 2012.

38. Berthet C, Guéhenneux F, Revol V, et al: Interaction of PRMT1 with BTG/TOB proteins in cell signalling: molecular analysis and functional aspects. Genes Cells 7: 29-39, 2002.

39. van Galen JC, Kuiper RP, van Emst L, et al: BTG1 regulates glucocorticoid receptor autoinduction in acute lymphoblastic leukemia. Blood 115: 4810-4819, 2010.

40. Pal S and Sif S: Interplay between chromatin remodelers and protein arginine methyltransferases. J Cell Physiol 213: 306-315, 2007. 